\title{
The Europeanization of Love. The Marriage of Convenience in European Migration Law
}

\author{
Betty de Hart
}

Centre for Migration Law, Radboud University Nijmegen/vu Amsterdam,

De Boelelaan 1105, 1081 HV, Amsterdam, the Netherlands

B.de.Hart@vu.nl

\begin{abstract}
The tension between the right to family reunification as laid down in European Directives and Member States' concern to protect their sovereignty in regulating migration has resulted in growing attention to and concern about fraudulent family relationships (especially marriages of convenience). This contribution addresses the question of what forms of control are permissible from a European law perspective and whether national practices are in conformity with European law and fundamental rights. Looking at these national practices several problems are identified: definitions of 'marriages of convenience' extending beyond what European law allows; systematic checks of certain nationalities/ethnic groups, mixed couples and/or gender may amount to discrimination and the burden of proof seems to be shifting to couples. Comparing control practices for marriages of convenience with those of homosexual asylum seekers, it is argued that human dignity is at stake.
\end{abstract}

\section{Keywords}

marriages of convenience - Union Citizens Directive - Family Reunification Directive - gender - ethnicity - discrimination - human dignity - mixed couples

* This article was written in the context of the late Sarah van Walsum's Vici-program Migration as a family matter, at Free University Amsterdam, funded by nwo.

(C) BETTY DE HART, 2017 | DOI 10.1163/15718166-12340010

This is an open access article distributed under the terms of the prevailing CC-BY-NC license at the time of publication. 
Family reunification is the predominant form of migration into the European Union. It is the main reason for migration in more than half of the E U Member States. ${ }^{1}$ The European Union laid down the right to family reunification in the Family Reunification Directive (2003/86/EC) and the Union Citizens Directive (2004/38/EC). However, Member States perceive a tension between this right, and their concern to protect their sovereignty in regulating migration. This has resulted in growing attention to and concern about fraudulent family relationships in the past decade. This attention focusses especially on fraudulent marriages - also known as sham marriages, bogus marriages or marriages of convenience - and, to a lesser extent, false declarations of parenthood. ${ }^{2}$ Both the Union Citizens and the Family Reunification Directives allow checks for marriages of convenience, and other forms of fraudulent family relationships. The European Commission guidelines to these Directives give directions on how to go about these checks. Additionally, the European Commission has developed a Handbook on Marriages of Convenience with the same aim.

Although at the European and national level, the need for controlling fraudulent family relationships has been widely acknowledged, its actual control practices have been severely criticized, by legal scholars as well as other academics. These critiques entail that the control practices constitute highly normative models of what constitutes a 'genuine' marriage or relationship, as well as investigation techniques that violate the privacy of the parties involved (see literature discussed below, par. 2). However valuable the normative evaluations by these academics, so far, the question of what forms of control are permissible from a European legal perspective has not been addressed. The main objective of this contribution is to fill this gap. It addresses two questions: 1. What are the legal constraints, if any, set by European migration law on what is allowed in control practices for marriages of convenience? 2. Are national control practices in conformity with these legal constraints?

To answer these questions, this contribution will first describe the relevant norms in the Union Citizens and Family Reunification Directives, the EC

1 Eurostat Residence permits statistics, http://ec.europa.eu/eurostat/statistics-explained/index .php/File:Main_groups_of_citizenship_granted_a_first_residence_permit_in_the_EU-28_ and_main_EU_Member_States_issuing_the_permit, _by_reason, _in_2015.png, last visited 9 November 2016.

2 See European Migration Network, Misuse of the Right to Family Reunification. Marriages of convenience and false declarations of parenthood (Luxembourg: Publications Office of the European Union, 2012). 
guidelines to both Directives and the Handbook on Marriages of Convenience, developed by the European Commission (par. 3.1. and 3.2). As this discussion will demonstrate, these Directives and related documents set important limits on control practices, especially under the European law principles of proportionality and non-discrimination (par. 3.3). On the other hand, the European legal framework also leaves Member States considerable room to choose different investigation techniques. It will be argued that there is a tension between the legal constraints set by the EU law principles of proportionality and nondiscrimination on the one hand and the investigation techniques that are considered permissible on the other hand, which is not solved in the documents that the EC has produced.

To fill this gap, this contribution turns to the $\mathrm{EU} \operatorname{CoJ}$ decision $A, B$ and $C$ on investigation techniques in the case of homosexual asylum seekers (par. 4). ${ }^{3}$ In this decision, the Court decided that investigation techniques should not violate the right to human dignity (art. $1 \mathrm{EU}$ Charter of Fundamental rights). A comparison of the checks on asylum-seekers' homosexuality and checks on marriages of convenience is useful, as they both involve the investigation of private matters, subjective feelings, as well as sexual and relational behaviour. Both are about the assessment of intimate relationships, love and sex as a technique of inclusion and exclusion: determining that an asylum seeker is a homosexual, or not, or that a couple has a genuine marriage, or not, grants or denies them rights of residence, and access to Europe. Furthermore, in both cases the question is what the legal constraints are for state authorities investigating these personal, intimate relationships within the context of migration policies. How can the norms developed in $A, B$ and $C$ be applied to evaluate control practices for marriages of convenience? Taking a look at available information on national control practices in several Member States, this contribution demonstrates that human dignity is equally at stake here.

This contribution is based on a variety of legal and non-legal sources: European documents on the implementation of the Directives, European and national case law, research reports, information from NGOs, media reports and academic articles.

A short note on terminology: The Union Citizens and Family Reunification Directives as well as related documents use the term 'marriage of convenience' to refer to marriages that are concluded with the sole aim of obtaining a residence right or right to free movement. The terms 'marriage fraud' or 'fraudulent marriages' are at times used to refer to the same phenomenon, while

3 Middelkoop, L., 'CJ EU 2 December 2014, C-148/13, C-149/13 and C-150/13, (A, B and C)', ECLI:EU:C:2014:2406; 3Jurisprudentie Vreemdelingenrecht (2015), annotation. 
it may also include fraudulent non-marital partnerships. The EC Handbook, however, makes a distinction between abuse and fraud, the latter being associated with presenting fraudulent documentation:

For instance, the submission of a forged marriage certificate with a view to obtaining a right of entry and residence under the Directive would be a case of fraud and not of abuse, since no marriage was actually contracted. ${ }^{4}$

Therefore, I will use the term referring to marriages of convenience which also includes non-marital relationships.

Before turning to the question of how European norms on fraudulent marriages have developed, the available academic literature will be discussed.

\section{Literature on Control Practices of Marriages of Convenience}

Marriages of convenience are a hot topic that triggers the imagination of many and often makes media headlines. For decades, Member States have put forward the argument that marriages of convenience are a serious problem, high in number, related to human trafficking and other criminal activities. Except for legal literature on control practices for marriages of convenience, much academic writing on the topic can be found outside legal academia, in sociology, anthropology, political science and gender studies. ${ }^{5}$ The general trend in both

$4 \operatorname{COM}(2014) 604$ final, 9-10.

5 The legal literature includes: Abrams, K., 'Immigration law and the regulation of marriage', 91 Minnesota Law Review (2007) 1625-1709; Wray, H.E., 'The "pure” relationship, sham marriages and immigration control', in: J. Miles, R. Probert \& P. Mody (eds), Marriage Rites and Rights (Hart Publishing, Oxford, 2015), pp. 141-165. See also Special Issue on Marriages of Convenience, 8 (3/4 European Journal of Migration and Law 2006).

Others: Bonjour, S. \& B. de Hart, 'A proper wife, a proper marriage: Constructions of "us" and "them" in Dutch family migration policy', 20 (1) European journal of women's studies (2013) 61-76; Charsley, K. \& M. Benson, 'Marriages of Convenience, and Inconvenient Marriages: regulating spousal migration to Britain', 26 (1) Journal of Immigration, Asylum and Nationality Law (2012) 10-26; D'Aoust, A., 'In the Name of Love: Marriage Migration, Governmentality, and Technologies of Love', 7 (3) International Political Sociology (2013) 258-274; Eggebø, H., 'A real marriage? Applying for marriage migration to Norway', 39 (5) Journal of ethnic and migration studies (2013) 773-789; Friedman, S.L., 'Determining "truth" at the border: immigration interviews, Chinese marital migrants, and Taiwan's sovereignty dilemmas', 14(2) Citizenship Studies (2010) 167-183; Lavanchy, A., The circulation of people. How does "race" 
strands of literature is to critically analyze the norms on 'love' and 'family' used in control practices. As American legal scholar Kerry Abrams has pointed out, in migration law norms on love and relationships are employed that would never stand outside the migration context. ${ }^{6}$ Political scientist Anne-Marie D'Aoust has developed the concept of 'technologies of love' to indicate the centrality of love as a norm in regulating marriage migration, that determines who gets in, and who belongs. These technologies of love, she argues, are tied to notions of modernity and liberalism. ${ }^{7}$ In a similar vein, Helga Eggebø has argued that the norms used in control practices for marriages of convenience in migration law resemble what sociologist Anthony Giddens has labelled the 'pure relationship' that is based on emotional and sexual equality as well as individual autonomy. ${ }^{8}$ It is entered into for its own sake, and only maintained as long as it delivers the partners sufficient—mainly emotional—satisfaction. Similarly, I have argued that control practices start from the assumption of a 'romantic ideal of marriage' that includes love as opposed to migration as a motive for marriage, and is attributed to couples who differ from each other e.g. in age, economic background, or cultural background. Both Eggebø and I have also argued that couples scrutinized for their motives may use narratives that convince the immigration authorities by showing not only 'true love', but also that this love is not naïve, or without reason and realism. The notion of a marriage of convenience not only implies love but also sex; both function as techniques of inclusion and exclusion. ${ }^{9}$

The insights provided by this multidisciplinary scholarship are highly relevant as they offer a critical lens through which to look at control practices and the norms, implicit or explicit, used in these practices as well as in the legal framework developed to guide such practices. As will be demonstrated in the following paragraphs, norms of love and sexuality are indeed central

matter in Switzerland?. Working Paper No. 7. (Neuchatel: Université de Neuchâtel, 2014); Messinger, I., 'There is Something about Marrying ... The Case of Human Rights vs. Migration Regimes using the Example of Austria', 2(4) Laws (2013) 376-391. Mühleisen, W., Å. Røthing \& S.H.B. Svendsen, 'Norwegian sexualities: Assimilation and exclusion in Norwegian immigration policy', 15 (2) Sexualities (2012) 139-155.

6 Abrams 2007. A point that has been made more broadly for migration law by Van Walsum, S., The Family and the Nation, Dutch Family Migration Policies in the Context of Changing Family Norms (Newcastle upon Tyne: Cambridge Scholars Publishing Press, 2008).

7 D'Aoust 2013.

8 Eggebø 2013; Giddens, A., The Transformation of Intimacy: Sexuality, Love and Eroticism (Oxford: Polity Press, 1992).

9 Luibhéid, E., Entry denied: Controlling sexuality at the border (Minneapolis/London: University of Minnesota Press, 2002). 
in European law and its implementation in national practices. The question that this scholarship does not answer, and that will be addressed in this contribution, is whether these norms are not only normatively but also legally questionable.

\section{European Norms on Marriages of Convenience in the Union Citizens and Family Reunification Directives ${ }^{10}$}

The concept of marriage of convenience appeared in EU migration law for the first time in the 1990s. The 1997 Resolution on the Combating of Marriages of Convenience noted that marriages of convenience constitute a means of circumventing the rules on entry and residence by third-country nationals, and that Member States should adopt equivalent measures to combat the phenomenon. ${ }^{11}$ The Resolution was not binding and had little effect in practice. Since then, a lot has changed. Interestingly, although during negotiations the issue of marriages of convenience raised most concern within the context of the Family Reunification Directive, after the Directives were implemented, it became an issue of concern above all within the context of the Union Citizens Directive, as the right to family reunification of Third Country National (TCN) family members of Union citizens became increasingly contested. ${ }^{12}$

\subsection{Union Citizens Directive}

Of course, the right of family members to establish themselves with the Union citizen, irrespective of their nationality, using his or her right to free movement is nothing new and has been acknowledged from the earliest legislation of the Commission in 1968. ${ }^{13}$ In 1992, in Surinder Singh, the European Court of Justice

10 The development of European norms on marriages of convenience up to its inclusion into the Union Citizens and the Family Reunification Directives has been described in Hart, B. de, 'The Marriage of Convenience in European Immigration Law', 8 (3/4) European Journal of Migration and Law (2006) 251-262. Therefore, this contribution describes this period only briefly.

11 The Resolution on the harmonization of national policies on family reunification adopted in June 1993 in Copenhagen and The Resolution on the Combating of Marriages of Convenience, 4 December 1997. 97/C 382/o1, Official Journal C 382, 16-12-1997.

12 Report from the Commission to the European parliament and the council on the application of directive 2004/38/EC on the right of citizens of the Union and their family members to move and reside freely within the territory of the Member States сом (2008) 840 final.

Art. 10 of Regulation 1612/68, OJ 1968, L 257/2. 
determined that after a citizen had made use of the right to free movement and worked in another Member State of the EU, s/he could return to the country of citizenship with the TCN partner under the more favourable conditions of EU law. ${ }^{14}$ Nevertheless, these rights have become increasingly controversial as the family reunification policies in various Member States became increasingly restrictive. Member States came to view the Surinder Singh judgment as a means for couples to circumvent restrictive national migration policies, the socalled 'EU route' or 'Europe route'. This is demonstrated by the Member States' response to the CJEU cases Akrich and Metock. In the 2008 report on the implementation of the Union Citizens Directive, the Commission noted that eleven Member States had introduced prior lawful residence in another Member State as a condition for the right of residence for TCN family members of $\mathrm{EU}$ citizens in response to the Akrich judgment of 2003. In Akrich, a British woman married a Moroccan national, who had tried in vain to gain lawful residence in the UK. She moved to Ireland with the express intention of moving back with her husband after a six-month period, after which her husband could gain lawful residence as the spouse of an EU citizen..$^{15}$ The British authorities, however, refused to grant a residence permit, because the husband had not had prior lawful residence. In Akrich, the Court introduced the additional condition of prior lawful residence. This judgment was probably also informed by the suspicion that the marriage of Mr. and Mrs. Akrich was one of convenience. The Court decided that the principle of free movement was not applicable when a Union citizen and TCN family member entered into a marriage of convenience in order to circumvent the provisions relating to entry and residence of TCNs. ${ }^{16}$

However, the condition of prior lawful residence that was endorsed by the Court was no longer allowed after the Union Citizens Directive came into effect. Prejudicial questions were asked after an Irish High Court proceeding on four applications by TCNS without legal residence whose requests to be granted residence with their British, German, and Polish wives were denied. This resulted in the Metock judgment of July 2008 in which the Court reversed the earlier Akrich judgment. ${ }^{17}$ In its judgment, the CJEU made clear that the condition of prior lawful residence was not in accordance with the Union Citizens

\footnotetext{
14 CJEU 7 July 1992, C-370/90 (Surinder Singh) ECLI:EU:C:1992:296.

15 CJEU 23 September 2003, C-109/o1 (Akrich) ECLI:EU:C:2003:491. In his conclusion to Akrich, the AG referred to the 1997 Resolution on combating marriages of convenience, nr. 44.

16 Akrich, 61.

17 CJEU, C-127/08, 13 September 2008 (Metock) ECLI:EU:C:2008:449. In Jia (C1/05 9 January 2007) ECLI:Eu:C:2007:1 and Eind (C-291/05, 11 December 2007) ECLI:EU:C:2007:771 the
} 
Directive. Again, the Court mentioned marriages of convenience, although there was no indication that the marriages in Metock were not genuine. The CJEU indicated that the Directive did not prevent Member States from combating abuse of Community rights, including marriages of convenience. It did so in response to the claim by the Irish Minister of Justice that the pressures of international migration necessitated a control of migration at the external borders of the EU. ${ }^{18}$ Hence, controlling marriages of convenience was linked to the sovereignty of states to control migration as a means of maintaining sovereignty in regulating migration.

At the European level, in their observations submitted in the proceedings on Metock, Member States expressed their concern that Metock would allow TCNS without legal residence to regularize their residence through marriage to an EU citizen. ${ }^{19}$ They expressed the same concern during a European Justice and Home Affairs meeting of 25 September 2008, where the Metock judgment was discussed, as well as in the European Commission report on the implementation of the Union Citizens Directive. ${ }^{20}$

At the national level, the Metock judgment was also critically discussed, as 'approving illegal migration through marriages of convenience', in the words of the Danish Minister, who also announced that the Danish government would aim for an amendment of the Union Citizens Directive. ${ }^{21}$ Similar words were used by the British, Irish and Dutch governments. ${ }^{22}$

It put the 'Europe route' and marriages of convenience on the European political agenda. In the conclusions of its report on the implementation of the Union Citizens Directive, the EC announced that abuse would remain a topic

Court had already nuanced the Akrich judgment. See Costello, C., 'Metock: free movement and "normal family life" in the Union', 46 (2) Common Market Law Review (2009) 587-622.

18 Metock, 74, 75. See also Lansbergen. A., 'Metock, Implementation of the Citizens' Rights Directive and lessons for EU citizenship', 31 (3) Journal of Social Welfare and Family Law (2009) 285-297.

19 Ten Member States, including Austria, Czech Republic, Cyprus, Denmark, Finland, Germany, Greece, Malta, the Netherlands, United Kingdom.

20 Report from the Commission to the European Parliament and the Council on the application of Directive 2004/38/EC on the right of citizens of the Union and their family members to move and reside freely within the territory of the Member States сом (2008) 840 final, p. 4 .

21 Lansbergen 2009, p. 291.

22 The Telegraph, 25 September 2008, "UK demands that EU closes "bogus marriages" immigration loophole'. In Dutch Parliament: Second Chamber, 27 January 2009, Proceedings $4646-4007$. 
for discussions on the transposition of the Directive. ${ }^{23}$ Subsequently, the 2009 guidelines to the Union Citizens Directive contained a more than two-page paragraph on marriages of convenience. ${ }^{24}$ During this process, the EC aimed to objectify and set standards for control practices for marriages of convenience.

They did so in the guidelines to the Union Citizens Directive, that set certain limits to what was allowed in control practices, and provided a set of socalled 'indicative criteria' suggesting the possible intention of abuse of rights. In 2012, fraud and abuse of free movement were mentioned in the Strategic Action plan for EU action to migratory pressures. A Handbook on Marriages of Convenience was published in September 2014. ${ }^{25}$ This Handbook specifically addresses marriages of convenience of EU citizens with TCN family members; it does not cover marriages between two EU citizens. Although the Handbook is not legally binding, its goal is helping Member States to ensure that their practices are based on the same factual and legal criteria and contribute to compliance with EU law. ${ }^{26}$ The legal constraints on control practices set out in the Handbook will be discussed in more detail below. First, let us take a look at the debate on marriages of convenience within the context of the Family Reunification Directive.

\subsection{Family Reunification Directive}

The Family Reunification Directive became effective on October 3, 2005. The first prejudicial questions answered by the Court of Justice give some indication of the far-reaching implications of the Directive, as it gives TCNs a right to family reunification, contrary to article 8 of the European Convention on Human Rights. ${ }^{27}$ The implication is that the conditions allowed by the Directive have to be interpreted restrictively, because family reunification is the rule. ${ }^{28}$ In 2010, this forced for instance the Netherlands to abolish its income

\footnotetext{
23 СОм (2008) 840 final, p. 10.

24 Communication from the Commission to the European Parliament and the Council, on guidance for better transposition and application of Directive 2004/38/EC on the right of citizens of the Union and their family members to move and reside freely within the territory of Member States, Сом(2009) 313 final, par. 4.2 p.15-17.

25 Council of the European Union, 23 April 2012, 8714/1/12, REV 1. COM (2014) 604 final. 26 September 2014.

26 сом (2014) 604 final. 269 2014, p. 3.

27 Groenendijk, K., 'Family reunification as a right under community law', 8(2) European Journal of Migration and Law (2006) 215-230.

28 Parliamentv Council, C 540/03, 27 June 2006.
} 
requirement for family formation of $120 \%$ of the minimum wage, introduced earlier in 2004, and lower the level to $100 \%$ of the minimum wage. ${ }^{29}$

The Commission report on the implementation of the Family Reunification Directive published in 2008 paid only limited attention to marriages of convenience. The report noted that every Member State had rules to prevent marriages of convenience and critically discussed control practices in Austria and the Netherlands, where systematic checks were taking place: in Austria, the registry office was obliged to inform the Aliens Police about every marriage involving a TCN and in the Netherlands every marriage involving a TCN without permanent residence required the prior advice of the Chief of Police. ${ }^{30}$ The Commission did not bring any infringement procedures against Member States, and decided against amendments to the Directive, apparently because it feared that proposals by Member States would lower the level of family reunification rights. Instead, it started a Green paper process, to gather options and information on the application of the Directive from Member States and NG Os. During this process, Denmark, the Netherlands and the United Kingdom pressured the European Commission to pay due attention to fraud and abuse. They pleaded for the instalment of a commission to study these issues, exchange of information between Member States and lowering the burden of proof. ${ }^{31}$ The Dutch also suggested tackling the Europe route by making all TCN family members, including those with an EU spouse, fall within the scope of the Family Reunification Directive. ${ }^{32}$ At this point, the EC tried to resist this pressure, arguing that Member States had not been able to provide statistics to support their claims of high numbers of fraudulent marriages. ${ }^{33}$

29 CJEU, C-578/08, 4 March 2010 (Chakroun) ECLI:EU:C:2010:117. Other relevant judgments are Noorzia (C-338/13, 17 July 2014) on the age requirement, and CJEU 9 July 2015, C 153/14, (Chakroun) ECLI:EU:C:2015:453 on pre-entry tests.

30 Report from the Commission to the European parliament and the council on the application of directive 2003/86/EC on the right to family reunification, СОм (2008) 610/3 final, p 10. This Dutch practice was condoned earlier by the European Commission of Human Rights, Klip and Krüger. 3 December 1997, appl. no. 33257/96. It was changed in 2015, the obligation to report to the Chief of Police was abolished. Staatsblad 2014, 587; Staatsblad 2015, 174 .

31 Summary report Seventh meeting of the European Integration Forum. Public Hearing on the Right to Family Reunification of Third Country Nationals in the EU, http://ec.europa .eu/ewsi/UDRW/images/items/static_38_597214446.pdf, p. 1.

$32 \quad$ Ibid., p. 6.

33 Green paper on the right to family reunification of third-country nationals living in the European Union (Directive 2003/86/EC), сом(2011) 735 final, p. 7. See also the report of the European Migration Network 2012, p. 67, which concluded that there was no statistical 
Nevertheless, efforts to develop rules and practices combating fraudulent marriages were further stepped up and the position of the EC started to shift gradually under the persistent pressure from Member States. In its guidance for application of the Family Reunification Directive published in 2014, the Commission spoke for the first time of the need to take 'firm action' against abuse and fraud. ${ }^{34}$ Furthermore, the Commission stated that it was allowed to make a distinction between family reunification and family formation in assessing cases, although the CJEU ruled that the Family Reunification Directive did not allow such a distinction. ${ }^{35}$

Finally, the Commission argued that the Handbook on Marriages of Convenience might serve as guidance for all three categories of marriages of convenience it had distinguished: between a TCN and another TCN residing in the $\mathrm{EU}$, a TCN and $\mathrm{EU}$ national exercising the right to free movement and-remarkably since this category is not covered by EU law-between a TCN and own national. The following paragraphs take a closer look at the legal constraints on control practices for marriages of convenience set out in the various documents.

\subsection{Legal Constraints of Directives, Ec Guidelines and Handbook}

Legal constraints are formulated in the Directives themselves, although more clearly in the Union Citizens Directive than the Family Reunification Directive. Article 35 of the Union Citizens Directive refers to the principles of proportionality and procedural safeguards in connection to refusal of residence on grounds of a marriage of convenience. For the Family Reunification Directive, the general provisions of articles 17 and 18, which require individual assessment and procedural safeguards, are relevant.

In the guidance to the Union Citizens Directive, the Commission has formulated several limitations. First, it is pointed out that the assessment of whether Community law has been abused must be carried out within the framework of Community law and not national law. Measures taken by Member States may not deter EU citizens and their family members from using their right to free movement or encroach on their legitimate rights and may not undermine the effectiveness of Community law. Discrimination on grounds of nationality is not allowed and fundamental rights, specifically the right to marry, respect of private and family life, rights of the child, prohibition of discrimination,

evidence for the high estimates of marriages of convenience by the media and Member States.

34 СОм (2014) 210 final, p. 3.

35 Chakroun, C-578/08, 4 March 2010. 
effective remedy and defence, as included in the EU Charter of Fundamental Rights and the European Convention on Human Rights need to be protected. ${ }^{36}$

Second, it points out that individual cases may be investigated only in cases of well-founded suspicions of abuse. ${ }^{37}$ Thus, systematic checks of all cases or certain categories of cases are not allowed. Member States may rely, however, on previous analysis and experience showing a clear correlation between proven cases and certain characteristics of such cases. The principles of proportionality, non-discrimination as well as the burden of proof are of importance here.

\subsubsection{Proportionality}

The principle of proportionality requires: a) a legitimate objective pursued; b) a measure must be suitable to achieve the objective; and c) a measure must be necessary to reach the objective. ${ }^{38}$ The proportionality test fails if less restrictive measures could be used to reach the same goal. The proportionality requirement applies not only to individual decisions, but also to the rules as such.

To the principle of proportionality, the Handbook explains that freedom of movement must be given a broad interpretation, and derogations from that principle must be interpreted strictly. The right to free movement cannot be restricted by unjustified and disproportionate measures by national authorities and measures may not be founded on the general presumption of abuse.

The principle of proportionality also requires an individual assessment, which must be based exclusively on the personal conduct of the individuals involved. Measures tackling abuse may not subject individuals to degrading treatment and must respect the integrity of the persons concerned. Investigation methods may not humiliate or debase the subjects, as this would violate article 4 of the Charter. ${ }^{39}$ As we will see in par. 4 that discusses of the $A$, $B$ and $C$ judgment, the Court of Justice refers to human dignity under article 1 of the Charter.

Referring to the ECtHR case law, the Handbook considers that Member States may delay an intended marriage of convenience, and require couples to notify their intention to marry and provide personal details, such as names, address, nationality etc. Interestingly, here the Handbook refers to the Klip and Krüger case on the same Dutch practices that the EC mentioned as a reason

\footnotetext{
$36 \quad$ сом (2009) 313 final, p. 15-16.

37 сом (2009) 313 final, p. 15-16.

$38 \quad \operatorname{com}(2014) 604$ final, p. 17-18.

39 No one shall be subjected to torture or to inhuman or degrading treatment or punishment.
} 
for concern years earlier. ${ }^{40}$ This demonstrates once more that the Commission has shifted in the direction of the Member States.

\subsubsection{Non-Discrimination}

The principle of non-discrimination in EU law means that measures against EU citizens may only be taken if they are also taken against own nationals. National rules aiming to prevent marriages of convenience may not discriminate on grounds of sex, race, colour, ethnic or social origin, genetic features, language, nationality, religion, political opinion, membership of a national minority, property, birth, disability, age or sexual orientation. Here, articles 4 and 21 (non-discrimination) of the Charter and 3 and 14 of the ECHR are relevant.

The Commission Handbook does not provide examples of national practices that may be disproportionate or constitute discrimination on any of these grounds. In past years, several Member States, including the United Kingdom, France and the Netherlands have developed new laws and practices for marriages of convenience. In 2010, the European Court of Human Rights scrutinized the British Certificate of Approval Scheme. ${ }^{41}$ According to this scheme, introduced in 2005, a migrant who was not an EU citizen and who did not have indefinite leave to remain needed permission from the Secretary of State of the Home Office in order to marry. After extensive national proceedings, the scheme was amended several times, allowing couples to submit information on the genuine character of their relationship, introducing exceptions in cases of compassionate circumstances and abolishing the fee. The ECtHR held that the right to marry (art. $12 \mathrm{ECHR}$ ) could be restricted to a certain extent to prevent marriages of convenience, but that in this case the right to marry had been violated because it excluded a certain category of people without sufficient leave to remain from marrying, which constituted a 'blanket prohibition'. The Court also considered the fee for the Certificate of Approval (£295 per partner, alongside the $£_{105}$ for marriage formalities and the fee for a residence permit) to be too high. The couple involved - a British woman and her Nigerian husband who had been living together for one-and-a-half years and had a child together-had, according to the Court, clearly been in a longstanding and permanent relationship. The Court also considered that there had been a violation of article 14 in conjunction with article $12 \mathrm{ECHR}$, because those marrying in the Church of England were exempted from acquiring

\footnotetext{
40 ECtHR, Klip and Krüger, 3 December 1997, application no. 33257/96.

41 ECtHR, O'Donoghue and Others v United Kingdom, Application no. 34848/07, 14 December 2010.
} 
the Certificate of Approval. Unfortunately, the Court did not go into the matter of whether there had been discrimination on grounds of nationality. ${ }^{42}$

\subsubsection{Burden of Proof}

The burden of proof to restrict rights under the Union Citizen's Directive lies with the national authorities. ${ }^{43}$ An assumption of innocence is required and it cannot be asked from applicants to prove that their marriage is not one of convenience. ${ }^{44}$ They are required to prove that their marriage is valid and still existing, not that it is genuine.

There needs to be a well-founded suspicion that the marriage is not genuine in order to justify checks on couples' motives. In the Handbook, it is spelled out that the authorities have to start by looking at 'hints' that there is no abuse, and not only look at hints that indicate abuse. If the couple fails to provide additional evidence that dispels the suspicion, this cannot be the only or decisive reason to conclude that the marriage is one of convenience; there have to be other relevant circumstances. It has to be duly established that the marriage is one of convenience, with the relevant evidential standard. As most evidence in these cases will be circumstantial, this must form a whole which taken together is corroborating evidence. ${ }^{45}$

As to the investigation methods, the Handbook supports the use of simultaneous and separate interviews with spouses, questionnaires filled in by the spouses to filter out cases to be interviewed, a solemn declaration about the information provided, document and background checks as well as police and community checks. The Commission does not go into the issue if and how these investigation techniques may be intrusive, invade privacy or may be disproportionate. Here, there seem to be few limits on what authorities can do.

\subsubsection{Indicative Criteria}

The guidance on the transposition of the Union Citizens Directive lists a set of indicative criteria suggesting the possible intention to abuse the right of free movement. These 'indicative criteria' or 'hints' as the Handbook calls them, are possible triggers for investigation, used to filter out the suspicious cases for further investigations, which is only allowed when more than one of these criteria are met.

\footnotetext{
42 For a discussion of ECtHR case law before the Directives, see De Hart 2006.

43 Сом (2009) 313, p. 17.

44 Handbook, p. 26-27, 34.

45 Handbook, p. 35.
} 
These indicative criteria are:

- The couple has never met before the marriage;

- Inconsistent statements about personal details, circumstances of their meeting, or other important personal information;

- The couple does not speak a language understood by both;

- Evidence of a sum of money or gifts handed over, not being a dowry in cultures where this is common practice;

- Past history of one or both spouses of prior abuse;

- Development of family life only after the expulsion order was adopted;

- Divorce shortly after TCN acquires a residence permit. ${ }^{46}$

The Handbook suggests that observing the conduct of the couple and identifying meaningful hints of abuse may reveal the 'real intentions' of the abusers. The hints relate to behaviour that can be found among abusive couples more frequently than among genuine couples. ${ }^{47}$ In this respect, abusive couples are 'different'; typical abusers trigger substantially more hints of abuse.

The Handbook lists hints in different stages of the relationship (before meeting, pre-marriage phase, wedding, applying for entry and residence in host state, end of marriage), which indicates that couples may be subject to surveillance for a period of years.

The Handbook spells out what the couple may or may not know about each other in terms of personal details and provide conflicting, inconsistent or false information about:

- personal details (name; date of birth, age, nationality, address, closest family members, previous marriages and relationships; education, profession and employment);

- circumstances of their first meeting;

- wedding ceremony, guests, witnesses;

- plans for the future, marital life and responsibilities of marriage.

In the phase of residence, the couple is expected to be more likely not to share responsibilities deriving from the marriage, such as parental responsibilities, living together, and financial stability. However, the Handbook indicates that individual circumstances have to be taken into account, e.g. that the couple

\footnotetext{
$46 \quad$ Handbook, p. 16-17.

47 Handbook, p. 33.
} 
has not lived together for a long time and therefore may not be informed about everyday habits. In other words, finding the hints is not enough, there may be explanations other than that the marriage is not genuine.

It is clear from this careful display of hints or indicators and the value that can be attached to them in terms of evidence, that the Commission is aware of the problems involved in proving marriages of convenience. However, the EC does not question the assumption that such hints are useful for revealing the true intentions of couples. And in spite of the efforts of the Handbook to provide standards of objective proof, none of the indicators or hints are about determination or proof of the actual motives for the marriage.

Instead, the hints or indicators point to what the academic literature discussed earlier typified as the 'technologies of love', the search for the 'pure relationship', or 'romantic marriage ideal' which are built on-often rather traditional-conceptions of what a genuine couple should look like and how they should behave. This issue will be addressed further below, in the discussion on national practices, which will be guided by principles formulated in the $A, B$ and $C$ case on homosexual asylum seekers.

\section{4 \\ Comparison with Determining the Homosexuality of Asylum Seekers}

In the CJEU decision $A, B$ and $C$, the Court looked into the question of what evidence can be used to determine the homosexuality of an asylum seeker, who seeks protection from persecution on this ground. ${ }^{48}$ Based on the academic discussion of this case, three aspects of the $A, B$ and $C$ decision can be identified that are equally relevant for couples being investigated as 'bogus': self-identification, the role of stereotypes and investigation techniques in relation to human dignity.

\subsection{Self-identification}

The Court in the $A, B$ and $C$ decision determined that self-identification by the asylum seeker of being homosexual was a starting point for further investigation, but not sufficient. Comments on the case referred to the ECtHR case of $K u c k$, in which it was determined that sexual self-definition-in this case by a transgender person - was the core of private life and could not be cast in doubt by the authorities. ${ }^{49}$ The ECtHR regarded this in light of the principles

$48 \quad A, B$ and C, C-148/13 to C-150/13, 2 December 2014.

49 Middelkoop 2015, 3. 
of personal autonomy and human dignity. The ECtHR also considered that science was not definite about the cause and nature of transgender and, therefore, authorities could not replace the notion of what it meant to be transgender with their own general assumptions. Middelkoop in his annotation to $A, B$ and $C$ derives from the Kuck case the notion that only the individual has the right to define his or her own identity, and that sexuality is so subjective and diverse that it is impossible to determine objectively. ${ }^{50}$ Because of the different approach of the CJEU, Middelkoop concludes that this Court attaches less value to the right to private life than the ECtHR. Another, in my view more plausible explanation, is that the right to private life is attached to a different value within the context of migration law. As already argued, different norms on family and private life are used within and outside the context of migration law. ${ }^{51}$ In a migration law case, even the ECtHR is likely to have ruled differently.

The parallels with marriages of convenience are obvious. As already mentioned, the definition of a marriage of convenience is that its sole purpose is to acquire the right to free movement or a residence right that would otherwise not exist. Although the definition does not spell out what the 'right' motive for a marriage is, in practice, the common assumption is that it should be about love.

Some Member States employ a definition that is broader than those in the Directives. For example, France and Belgium define a marriage gris (grey marriage) as a marriage in which the foreign partner betrays the other partner by letting him or her believe it is about love, while the foreign partner only has a residence permit in mind. ${ }^{52}$ In a letter to the Dutch Parliament, the Deputy Minister claims to have succeeded in broadening the definition of marriages of convenience in the Handbook from the 'sole aim' to the 'primary aim' to acquire residence rights. ${ }^{53}$ Indeed, the Handbook states:

A marriage by deception arises when the EU spouse is deceived by the non-EU spouse to genuinely believe that the couple will lead a genuine and lasting marital life. Such marriage is a marriage of convenience and

$50 \quad$ Middelkoop 2015, p. 2.

51 Abrams 2007, Van Walsum 2008.

52 Saldeco Robledo, M., 'Couples Binationaux de Meme sexe: Politque de soupcon, normalization et rapports de Pouvoir', 25 (150) Migrations Societé (2013) 95-108; Block, L., Policy Frames on Spousal Migration in Germany Regulating Membership, Regulating the Family (Wiesbaden: Springer, 2016), p. 183 .

53 Letter Deputy Minister Security and Justice Dijkhoff, 'Aanpak Schijnhuwelijken', 19 May 2015,647565 . 
should be tackled accordingly, with due regard to the innocence of the EU spouse. In such marriages, the EU citizen is not a willing accomplice, but a victim guilty only of good faith. ${ }^{54}$

It is remarkable that the EC defines marriages of convenience to include the marriage gris as it is the definitions in the Directives that count and, according to the CJ EU, concepts of the Directive have to be interpreted restrictively and according to European law and not national law. ${ }^{55}$ Thus, it is not permissible for Member States to use such broader definitions of 'marriage gris' or primary aim.

Just as declaring oneself to be homosexual is not enough for asylum seekers, declaring 'love' is not enough for couples, but just the starting point for investigation. In order to be labelled a genuine couple, the partners need to demonstrate certain characteristics and behaviour in order to convince authorities of their genuine love for each other.

The EU Handbook describes what a genuine couple looks like: a genuine couple is more likely to have no residence issues, have a close relationship for a long time, share on equal footing parental responsibility for children, have a common domicile or household, a serious long-term financial commitment, and a long lasting marriage. This description of a genuine couple includes all aspects of the pure relationship or romantic marriage ideal and techniques of love as analyzed by the academic literature.

In practice, the couple needs to convince the immigration official that they are really in love, but not only by declaring love. This can be illustrated by a 2013 Dutch court case, in which the civil registry had refused to conclude the marriage between an Egyptian man and a Hungarian woman. The registry office had based the refusal on the ground that the partners did not share a common language and that the 'personal attitude and behaviour' of the couple had raised serious doubts about their marriage, without explaining what this conspicuous behaviour entailed. It seems to hint at what Lavanchy describes in her study on Swiss registry officers, who often claimed that it was 'obvious' which couples had a marriage of convenience, something they could see, know immediately by looking at couples, based on gut feelings. ${ }^{56}$ In the Dutch court case, the couple explained their love, but also their choices and behaviour:

\footnotetext{
54 Handbook, p. 12.

55 Chakroun, C-578/08.

56 Lavanchy 2014.
} 
Applicants claim that they have an affective relationship. They also claimed that the woman had been pregnant for a few months and that the husband had legally acknowledged the unborn baby. Applicants think it is relevant that the man obtains a residence permit so that he can acquire the right to work and take care materially of the woman, who has because of her age and English language ability, no good labor market position.(...) The woman has declared that during her stay in Hungary she realized that she wanted to share her life with the husband. (...) At the court session the couple maintained that they love each other and this is the reason they want to marry (translation from Dutch by author). ${ }^{57}$

The family judge in this case concluded that, indeed, the woman spoke no English, no Dutch and no Arabic, so that it could be assumed that the verbal communication between the partners was limited. According to the court, however, this was not an impediment to marry and it was not up to the court to judge the quality of the relationship between the partners. ${ }^{58}$

In British and French control practices, authorities look for evidence of the performance of a genuine wedding ceremony: wedding rings, wedding pictures in the living room, wedding dresses and wedding parties. Cheap suits, lack of wedding rings or a low number of guests are all understood as hints of marriages of convenience. ${ }^{59}$

In short, self-identification, in the form of a declaration of love is not enough. A couple has to be able to produce a convincing narrative about their love, as well as perform their love in certain ways considered 'normal' for genuine couples.

\subsection{The Role of Stereotypes}

Research on homosexual asylum seekers has demonstrated that the determination of homosexuality often depends on the use of stereotypes about homosexual behaviour. The first question is whether homosexuality is about sex or identity. The 'real' homosexual, it seems, not only has homosexual sex, but also has a homosexual identity. It is also assumed that homosexuals go through a personal struggle, a psychological process of accepting their identity. This seems all the more important when an asylum seeker comes from a Muslim majority country 'where homosexuality is not generally accepted.' Asylum

\footnotetext{
57 Family Court, Eastern Brabant, 11 December 2013 (not published).

58 Ibid.

59 Charsley \& Benson 2012; Wray 2015. Cimade? Amoureux au ban public, Peu de meilleur et trop de pre, Paris 2008.
} 
seekers are also expected to have knowledge of the homo-scene in the country of residence as well as the country of origin, e.g. places to meet, organizations, or TV personalities. ${ }^{60}$

In $A, B$ and $C$, the European Court determined that questions about certain stereotypes on homosexuality could be useful in some circumstances, but also problematic. Middelkoop discusses the problem of using such stereotypes: they may become too important in the interview, may make the asylum system vulnerable to misuse, because anyone can learn by heart the 'correct' answers, and because individuals may present themselves differently, anticipating these stereotypes, as a form of self-disciplining. ${ }^{61}$

As we have seen, the EC guidelines and Handbook on Marriages of Convenience explicitly warn against stereotyping. They also warn against discrimination on grounds of nationality. Nevertheless, in various European countries, certain combinations of nationalities are considered suspect, e.g. in the UK: British and Pakistani, Nigerian or Indian, Portuguese or Polish sponsors with Pakistani. ${ }^{62}$ In the Netherlands, Poles with Egyptians and Bulgarians with Turks are mentioned as 'combinations of nationalities' that are 'not obvious.' 63 What is more, in several Dutch court cases, the Dutch Immigration Services mention 'cultural and religious differences' between partners as an indicator of marriages of convenience. ${ }^{64}$ In other words: it seems that (ethnically) mixed couples are more often framed as marriages of convenience than ethnically homogenous couples. Lavanchy is one of the few authors who expressly addresses this issue. ${ }^{65}$ Deviance, one of the aspects of the normative marriage ideal, involves not only differences in age or language, but also cultural and ethnic or racial differences. According to Lavanchy, the seemingly 'objective' marker of nationality relates to physical appearance and racialised notions of how partners should match. ${ }^{66}$

Control practices are also highly gendered, as several authors have noted. Messinger observes that in Austria, especially marriages between Austrian women and TCN men are investigated, although marriages between Austrian

6 Jansen, S., 'Herken de homo', 39 (5) Justitiële Verkenningen (2013) 44-6o. See also Spijkerboer, T., Fleeing homophobia: Sexual orientation, gender identity and asylum (Abingdon: Routledge, 2013).

61 Middelkoop 2015.

62 Charsley \& Benson 2012.

63 Bonjour \& De Hart 2013.

64 Court Den Bosch 23 August 2013, ECLI:NL:RBDHA;2013:11310; Higher Court Arnhem 9 April 013, AWB12/23279.

65 See also Abrams 2007, p. 1688.

66 Lavanchy 2014, p. 12. 
men and TCN women are much more frequent. ${ }^{67} \mathrm{~A}$ similar pattern can be found in other countries; Norwegian practice demonstrates that marriages of convenience are attributed more to Norwegian women with foreign men than the other way round. 68

Although the EC guidelines warn against stereotyping they also leave room for control practices built on earlier experiences. There is a tension here, as many immigration officials would claim that it is their 'experience' that marriages of convenience can be found more frequently among female sponsors, or among Egyptians. When do such practices based on 'experience' amount to discrimination on the basis of race/nationality and/or gender?

Member States seem to be aware of the problem and argue that their practice is not discriminatory. The British government defends the use of risk profiles that are based on, among other factors, nationality and ethnicity as non-discriminatory because there are, in their view, objective justifications and not every couple is subjected to further investigation. ${ }^{69}$

In the Netherlands, a group specifically targeted is Egyptians who marry an EU citizen at the Egyptian embassy. This control practice was based on information from the Ministry of Foreign Affairs about an increasing number of marriages concluded at the Egyptian embassy. It almost exclusively involved Eastern European women and as an indicator that these marriages were marriages of convenience, it was mentioned that the couples often did not share a common language, and that after the marriage an application for the right to free movement was lodged. The Minister claimed that this did not amount to systematic checks of a particular group of migrants, as only those marrying at the Egyptian embassy were checked, and not all Egyptians. ${ }^{70}$ The Dutch Advisory Committee on Migration Affairs has argued that risk profiles are being used in the control practices for marriages of convenience. ${ }^{71}$

It is up to the courts to decide whether these arguments are convincing. Nationality or ethnicity may not be the only factor taken into account, but putting forward the lack of common language, or the application for a residence

\footnotetext{
$67 \quad$ Messinger 2013.

68 Mühleisen, Røthing \& Svendsen 2012.

69 Memorandum Home Office Immigration Bill European Convention on Human Rights, October 2013, https://www.gov.uk/government/uploads/system/uploads/attachment_ data/file/249270/Immigration_Bill___ECHR_memo.pdf, last visited January 24, 2017.

70 Court The Hague, zp Haarlem, 27 January 2011, AwB 10/37306.

71 Advisory Committee on Migration Affairs, Profileren en Selecteren. Advies over het gebruik van profilering in de uitvoering van het vreemdelingenbeleid (The Hague: Advisory Committee on Migration Affairs, 2016), p. 12.
} 
permit, hardly seems convincing evidence as explained by the European Commission. Is it really justified to check all marriages involving Egyptians without residence status and not all Americans without residence status?

Furthermore, the Dutch practice of reference to cultural and religious differences between partners as an indicative criterion for marriages of convenience is, in my view, an unacceptable form of stereotyping of mixed couples that amounts to discrimination. There is no reason why mixed couples would be more prone to abuse and fraud than other, non-mixed couples, and why cultural and religious differences between partners would be an indicator of that.

\subsection{Investigation Techniques and Human Dignity}

In the $A, B$ and $C$ case, the Court determined that some techniques of investigation were not permissible, referring to articles 1 (human dignity) and 7 (right to private life) of the EU Charter of Fundamental Rights. The Court prohibited detailed questions about the arrangement of sexual practices; which questions are considered too detailed, however, are not clear. The Court also prohibited the use of (physical and psychological) tests and visual media registering sexual behaviour, even if the asylum seeker offered this material voluntarily. Sexual orientation is part of human dignity and human dignity cannot be given up voluntarily, the Court argued. ${ }^{72}$

As already mentioned, the Commission warns that control practices for marriages of convenience should not violate human dignity and that questions cannot be degrading or humiliating. On the other hand, the Commission has also indicated that couples can be required to fill out a questionnaire in order to filter out suspicion, and that couples are obliged to cooperate.

The Dutch Immigration Services' application form for a residence permit or long-term visa for family reunification in cases of non-marital relationships, includes a list of twelve questions, used to filter out suspicious cases:

1. How long have you known your partner? Mention day, month and year.

2. How did you come into contact with each other?

3. Where did you meet your partner? Mention name and precise location.

4.1 If you met through the internet or family, have you met each other in person?

4.2 If so, when and where? If not, why not?

72 Terlouw, A., 'Uitspraak van de maand, Seksuele gerichtheid onderdeel van menselijke waardigheid, 10 Asiel \& Migrantenrecht (2014) 446-449. 
5. How long have you had a love relationship? Mention day, month and year? How did this happen?

6. How did you maintain the relationship from the start? Please provide as much evidence as possible, such as letters, e-mails, photographs and plane tickets.

7.1 Has your partner visited the Netherlands before? If so, when? Mention day, month and year.

7.2 What was the reason for this stay?

7.3 In what town and where did your partner stay?

8. Have you had a relationship before with someone who came from abroad to the Netherlands for you? If so, with whom and when?

9. Has your partner had a previous relationship with someone from the Netherlands? If so, with whom and when?

10.1 Does you partner have minor children?

10.2 If so, what are their names, ages and where are they now?

11.1 Will the children travel to the Netherlands with your partner?

11.2 If not, why not? Who will take care of the children when your partner leaves for the Netherlands?

12. Are you related to your partner? If so, what is the family relationship? ${ }^{73}$

All applicants for residence for a partner relationship (not marriage) have to answer these questions, irrespective of the nationality of the TCN partner. The form explains that if the information and evidence provided is not extensive enough, the application will be rejected.

The question is whether this goes beyond the requirement of a 'duly attested' durable relationship (art. 3 section 2 sub b Union Citizens Directive).

For marriages, such questionnaires would amount to systematic checks that are not allowed. In a British court case, an Armenian woman married to a Greek national for twelve years and who had two children with him, saw her request for a short $\mathrm{U} \mathrm{K}$ visit rejected because she did not provide wedding photographs, or proof that they shared a household. It took eighteen months and three hearings before the visa was granted. The Upper Tribunal thought the belief that there was a marriage of convenience in this case 'ludicrous' and

73 Form for application for a long term visa for family reunification, for third country nationals with a Dutch or TCN partner. Downloaded from their website, last visited 24 January 2017 . 
decided that documents other than those mentioned in article 10 of the Union Citizens Directive could only be required if there were grounds for suspicion. ${ }^{74}$

There are indications that some Member States' interview practices digging into the personal and sexual lives of couples may harm human dignity. NGOs in France report questions about the couples' sex life: has the marriage been consummated, how often do you have sex, what was the date of the first and the last sexual intercourse ${ }^{75}$ Dutch case law indicates that questions are being asked about whether the couple slept together on their first date. ${ }^{76}$

Interview techniques may also be humiliating more generally. Several authors report that couples find the control practices humiliating and degrading. ${ }^{77}$ In Belgium, media reports indicate that immigration police comment in derogatory terms on the physical appearance and character of Belgian women who want to marry a foreign husband:

Interviewer: 'Should one not try to change the mind of such a woman?'

Policewoman 1: 'That is easier said than done. Women in love, that is the most terrible thing, they are not open to reason. Many tears ran during such a conversation. I always have a box of Kleenex on my desk, at the end of the week it is empty.'

Policewoman 2: 'I am harsh. "Madam", I say, "look at these pictures. Do you really believe that this hunk is in love with you, while there are so many young, handsome girls round?" But like she says: they don't want to listen.' (translation from Dutch by author). ${ }^{78}$

In Norway, the term 'hormonal disturbances' is en vogue to typify the same kinds of relationships between (older) ethnic Norwegian women and TCN men. ${ }^{79}$ The question of how these understandings, based on social norms and

74 Upper Tribunal IAC Paparkorgi EEA spouse marriage of convenience Greece [2012] UKUT 00038 (IAC) 9 December 2011.

75 Cimade, Les Amoureux au ban Public, Peu de meilleur et trop de pire (Paris: Cimade, 2008), http://www.amoureuxauban.net/wp-content/uploads/2013/07/Rapport_Cimade_ Couples-Mixtes.pdf, last visited 24 January 2017.

76 Administrative Jurisdiction Division Council of state, ABRvS 26 May 2016, ECLI:NL: RVS:2016:1546.

77 Messinger 2013; Eggebo 2013; De Hart, B., Onbezonnen vrouwen. Gemengde relaties in het nationaliteitsrecht en het vreemdelingenrecht (Amsterdam: Aksant, 2003), ch. 7 .

78 'Schijnhuwelijken: Verliefde vrouwen, dat is het ergste wat er bestaat', Knack, 6 November 2013, http://www.knack.be/nieuws/belgie/schijnhuwelijken-verliefde-vrouwen-dat-ishet-ergste-wat-er-bestaat/article-normal-114564.html, Last visited 24 January 2017. Mühleisen, Røthing \& Svendsen 2012, p. 145. 
stereotypes about female and migrant sexuality, inform control practices deserves further research.

\section{$5 \quad$ Concluding Remarks}

This contribution has demonstrated how control practices for marriages of convenience have become subject to Europeanization. European definitions and norms on what constitutes a 'genuine' or 'sham' marriage have been formulated in European Directives and related documents. For a large part, this was the result of pressure by Member States that perceive the concept of marriage of convenience as a tool to maintain their sovereignty in regulating migration within a European legal framework that limits their room to do that. In its turn, the negotiations at European level and the resulting documents have resulted in intensified control practices for marriages of convenience in various national contexts, as Member States felt European law and the European Court of Justice allowed them to do so.

EU law allows Member States some discretion in arranging their national control practices. But what exactly does this discretion look like? This contribution has been an effort to answer this question. Because the guidance to the Family Reunification Directive refers to those of the Union Citizens Directive and the Handbook, the legal constraints are similar, regardless by which Directive a certain case is covered. Practices also have to be in line with articles 8 , 12 and 14 ECHR and with the European Charter, especially articles 1 and 7 . Proportionality and non-discrimination are guiding principles.

Looking at national control practices, at least four possible problems have been identified:

- Definitions of 'marriages of convenience' that extend beyond what the definitions in the European Directives allow (marriage gris, primary aim);

- Systematic checks of certain nationalities/ethnic groups, combination of nationalities, or culturally and religiously mixed couples may amount to discrimination;

- If couples of a female sponsor are checked more frequently than those of men in spite of their lower number of family reunifications, this may amount to indirect discrimination on grounds of gender (art. 8 and $14 \mathrm{ECHR}$, 7 and 21 EU Charter);

- Burden of proof placed on couples if they have to provide detailed information on their relationship, photographs, letters, emails, etc. without there being a suspicion; 
- Investigation techniques that violate human dignity (art. 1 Charter EU) such as questions about sex or degrading comments on looks, gender and age.

In order to assess these possible violations with more certainty, additional, international comparative empirical research on national practices as well as litigation challenging these practices is needed. It can be helpful to include insights from non-legal academic disciplines that have critically evaluated the norms underlying the concept of marriages of convenience. Such critical evaluations may help us to move beyond the love/abuse dichotomy to directly challenging the norms underlying these control practices (e.g. challenging the notion that lack of a common language, age difference or cultural and religious differences are useful indicators).

Last but not least, like (homo)sexuality, love is so subjective and diverse that it is impossible to establish it objectively. This means that checks for fraudulent marriages are always and inherently problematic and hazardous. That is why these practices deserve to be more critically scrutinized by lawyers, legal scholars and national and European courts. This article hopes to contribute to such critical scrutiny. 